\title{
Measuring Environmental Sensitivity in Educational Contexts: A Validation Study With German-Speaking Students
}

\author{
Teresa Tillmann ${ }^{1}$, Katharina El Matany ${ }^{2} \&$ Heather Duttweiler ${ }^{1}$ \\ ${ }^{1}$ Ludwig-Maximilians-University Munich, Germany \\ ${ }^{2}$ Humboldt University Berlin, Germany (at the time the study was conducted); current position at Schiller \\ Gymnasium Potsdam, Germany \\ Correspondence: Teresa Tillmann, Faculty of Psychology and Educational Sciences, \\ Ludwig-Maximilians-University Munich, Germany. Tel: (00)49-89-2180-72114. E-mail: \\ teresa.tillmann@edu.lmu.de
}

Received: April 24, 2018 Accepted: May 23, 2018 Online Published: May 30, 2018

doi:10.5539/jedp.v8n2p17 URL: http://doi.org/10.5539/jedp.v8n2p17

\begin{abstract}
Sensory-Processing Sensitivity (SPS), as part of the general theory on Environmental Sensitivity (Pluess, 2015), is a temperamental individual difference variable, referring to sensitive perception and processing of as well as reflection upon environmental stimuli. For its measurement, Aron and Aron (1997) developed the Highly Sensitive Person Scale (HSP Scale) for application with adults. However, despite some adaption into German (Konrad \& Herzberg, 2017) and a first English version for children (Pluess et al., 2018), no suitable measures of SPS for children exist in German. The presented two studies aimed at developing and validating a short, 10 -item German version of the scale, which can be administered efficiently in educational field studies with German-speaking secondary school students. The factorial structure, its relationship with other personality traits (i.e., the Big Five; McCrae \& Costa, 1990) and exploratory analyses on relationships with additional school-related variables were revealed using data from two independent student samples $(N=301$ German academic-track secondary school students and $N=460$ German vocational track secondary school students). Relations to existing research, practical implications for the educational context, and limitations of the studies are discussed.
\end{abstract}

Keywords: education, Environmental Sensitivity, Sensory-Processing Sensitivity, validation

\section{Introduction}

Heterogeneity within groups of learners plays an important role in educational research. This does not only include diversity with regard to culture, religion or language, which currently can be increasingly observed in school classrooms due to migration movements or education policies, including for example inclusion (United Nations, 2006), but also regarding personality traits. Those inter-individual differences are of increased interest and importance in empirical studies (Steinmayr, Dinger, \& Spinath, 2010, 2012). Due to its wide acceptance in the field of personality psychology, the Five Factor Model of Personality (McCrae \& Costa, 1990) has been the main focus of investigations of personality in relation to different variables such as performance outcomes (e.g., Noftle \& Robins, 2007). Because these personality theories often disregard environmental aspects, the recently suggested theory on Environmental Sensitivity (Pluess, 2015) is a relevant addition to this area of research. It summarizes numerous theoretical frameworks on individual differences with regard to the depth of processing of environmental information and stimuli, including the theory on Sensory-Processing Sensitivity (Aron \& Aron, 1997). Although studies applying this framework to the educational context are still missing, it is assumed to significantly contribute to a better understanding of the relationships between students' personality, their well-being and performance at school as well as their future development.

\section{Theoretical Background on Environmental Sensitivity and Sensory-Processing Sensitivity}

\subsection{Definition of Environmental Sensitivity}

In the last decades, various theories have investigated the influence of temperamental differences in the development of children (e.g., "Differential Susceptibility", Assary \& Pluess, 2017; "Biological Sensitivity to Context", Boyce \& Ellis, 2005; for a review, see Belsky \& Pluess, 2013). In particular, the main focus was the effect of environmental influences on developmental processes and the common finding that " [...] children differ 
substantially in Environmental Sensitivity, with some being more and some less affected by contextual factors [...]" (Pluess et al., 2018, pp. 51-52).

This general theory of Environmental Sensitivity (for a more detailed description, see Pluess, 2015) summarized various theoretical frameworks that have been suggested in the last decades. In addition to the two aforementioned theories about child development, a third theory, called Sensory-Processing Sensitivity (SPS; Aron \& Aron, 1997), has gained acceptance in the field of personality psychology. It is suggested to be a temperamental trait, referring to the way people perceive and process novel stimulation from their physical and social environments (Aron \& Aron, 1997; for a review, see Aron, Aron, \& Jagiellowicz, 2012). Individuals who are high in SPS have been described as being "particularly sensitive to subtle stimuli, easily overstimulated, prone to 'pause to check' in a novel situation, and prefer[ring] to reflect and revise their cognitive maps after an experience" (Aron, Aron, \& Davies, 2005, p. 181). It is suggested that a small proportion of people in the population are more sensitive (e.g., Aron \& Aron, 1997; for a recent statistical analysis, see Lionetti et al., 2018).

\subsection{Measuring Environmental Sensitivity}

In order to measure Environmental Sensitivity, the Highly Sensitive Person Scale (HSP Scale) developed by Aron and Aron (1997) is often applied, thus far mainly applied to samples of undergraduates or other adults. While reliability measures of the scale were supported in numerous studies (e.g., Konrad \& Herzberg, 2017; Pluess et al., 2018), results of the scale's validity, particularly with regard to the factorial structure, revealed different solutions. The majority of findings range from a unidimensional (e.g., Aron \& Aron, 1997) or a two-factorial structure (e.g., first suggested by Evans \& Rothbart, 2008, factors Temperamental Negative Affect and Orienting Sensitivity) to three factors (Smolewska et al., 2006; factor Ease of Excitation, factor Aesthetic Sensitivity and factor Low Sensory Threshold; see also Konrad \& Herzberg, 2017).

Summarizing the literature indicates the most common findings have two or three factors, leading to the suggestion of the existence of one or two SPS facets that are closely related to neuroticism and proneness to experiencing negative affect (Evans \& Rothbart, 2008: factor Negative Affect; Smolewska et al., 2006: factor Ease of Excitation and factor Low Sensory Threshold). Another SPS facet reflects a positive openness to stimuli (Evans \& Rothbart, 2008: factor Orienting Sensitivity; Smolewska, et al., 2006: factor Aesthetic Sensitivity) that displays only a slight relationship with neuroticism and negative affectivity (Evans \& Rothbart, 2008; Smolewska, et al., 2006; Sobocko \& Zelenski, 2015). Studies also investigated convergent and discriminant validity (e.g., for a recent analysis, see Pluess et al., 2018) of the scale and revealed results in support of the construct. With regard to the discriminant validity, the most common measurement investigated is that measuring the Big Five personality traits (McCrae \& Costa, 1990; see for example Smolewska et al., 2006, or Pluess et al., 2018).

Additionally, the scale has been translated into different languages, including Chinese (Jagiellowicz et al., 2011), Dutch (Evers, Rasche \& Schabracq, 2008), and German (Konrad \& Herzberg, 2017). All three translated versions, however, have been designed to be applied to adult samples. Therefore, they contain complex phrases that could confuse some students and are not seen as useful for children (e.g., "When you were a child, did parents or teachers seem to see you as sensitive or shy?") or not applicable to many children's lives (e.g., "Do you make a point to avoid violent movies and TV shows?"). Furthermore, the scales are based on the original 27 -item version, which is not easily applicable in field research where time for assessment is typically very limited. The only shorter version for children with 12 items has been adapted recently in a UK-based sample and therefore is only available in English (Pluess et al., 2018).

\subsection{Environmental Sensitivity and Measures of Well-Being}

Although recent theoretical and empirical developments in the area of Environmental Sensitivity, including the theory of "Vantage Sensitivity" (see Pluess, 2017), suggested that people scoring high on Environmental Sensitivity measures (i.e., the HSP scale) might also benefit more from positive experiences and supportive environments (Pluess, Boniwell, Hefferon, \& Tunariu, 2017), the main focus of research on the relationship with psychological well-being focuses on negative effects, indicated by associations with physical and psychological discomfort (e.g., Bakker \& Moulding, 2012; Benham, 2006). Evidence suggesting positive effects of supportive environments on the different revealed factors, such as sensitive openness, exists (e.g., Sobocko \& Zelenski, 2015), but is still scarce, inconsistent, and displays a research gap.

\subsection{Environmental Sensitivity in Educational Contexts}

Based on the specific characteristics that go along with higher levels of Environmental Sensitivity and supported, for example, by results by Maher and van Hippel (2005) in open-plan offices in an occupational environment, it could be assumed that concentrating in a classroom is more difficult for students with higher sensitivity. Due to the 
constant noise, sudden and unpredictable disruptions, and the lack of opportunities to retreat, students might become easily overwhelmed. This, in turn, can lead to regular overstimulation and, in the long run, possibly lower well-being and lead to poorer performance. However, not only noises in the classroom and the lack of time alone to process stimulation would put higher demand on students with high environmental sensitivity, but also specific requirements and assignments, such as presenting in front of the whole class, can make it difficult for students to thrive and can consequently finally result in disadvantages for certain students. Lastly, the education context could be of significant importance for students' development and future well-being. Existing findings suggest, for example, that unsupportive environments might lead to people experiencing more negative affect later in life (Aron et al., 2005). At the same time, individual research studies do suggest the positive effects of supportive environments (e.g., Pluess et al., 2017).

Because school is an important institution in children's lives, in which they not only spend most of their time, but that also provides various important opportunities for different kinds of experiences for students' developments, it is assumed that differences in Environmental Sensitivity may play a crucial role in educational contexts as well and make it a research gap that has to be addressed. However, in order to realize this application, a reliable and valid self-report measure that can be applied with children needs to be made available. While a first English version of the self-report measurement of Environmental Sensitivity suitable for children has been adapted recently in a UK-based sample (Pluess et al., 2018), a German version is still missing to this day. Therefore, in addition to a first exploratory study of relationships between Environmental Sensitivity and additional school-related variables, the development of a scale that can be applied in the school context is the main goal of the present studies.

\section{Goals of the Present Paper}

Based on these research gaps and the desideratum for the development of a German scale for students stated above, the present paper includes two studies on the development, validation, and application of a self-report scale measuring Environmental Sensitivity in the educational context. While the first study aims at investigating psychometric properties of a first translated and adjusted version of the HSP scale in a sample of academic track secondary school students, a further adjusted and shortened version of the scale was subsequently administered to an independent second sample as part of a second study. In addition to a repeated validation of the scale, this study further aimed at exploring relationships with additional school-related variables.

\section{Study 1: Translation and First Validation of HSP Scale for Children}

The aim of Study 1 was to examine the factorial structure of a newly-developed and translated preliminary SPS measure in a sample of German academic track secondary school students. Furthermore, it aimed at analyzing the psychometric properties of the scale and eliminating the items that do not meet quality criteria. Existing research on the original HSP Scale resulted in solutions from one to three factors (Aron \& Aron, 1997; Evans \& Rothbart, 2008; Smolewska et al., 2006). These inconsistencies require more research on the factorial structure to answer the question whether SPS can be represented by one factor or whether there may be different facets that measure different aspects of one trait.

\subsection{Research Questions}

Research question 1: Which already established factorial structure does the data of the present sample follow?

Research question 2: Do all items meet the required criteria (i.e., reliability and factor loading), indicating a measurement of high quality, or do some of the items have to be deleted?

\subsection{Method}

Based on the aforementioned contradictions and the fact that our measure was not identical to the previous HSP Scale, we applied exploratory factor analysis in study 1.

\subsubsection{Participants}

Students $(N=301)$ from a German secondary school of the academic track (German: Gymnasium) voluntarily participated ( $n=135$ female) in the study. All students attended grades 9 to 13 and were 16 years of age on average $\left(S D_{\text {age }}=1.45\right)$.

\subsubsection{Procedure}

After consent forms from students, parents, and the principal were collected, one researcher introduced this study as investigating different personality traits and their relationships to various perceptions in everyday school life. The printed questionnaires were subsequently distributed during a lesson. Anonymity and confidentiality was ensured. If students did not agree to participate in the study, this did not result in disadvantages of any kind. 


\subsubsection{Measurement}

The students completed 25 items that were built in accordance with the theory of SPS (Aron \& Aron, 1997; Aron et al., 2012; e.g., "I am empathetic"). We made the wording such that the content was fitting to younger respondents, including children. The items were answered on 4-point scales $(1=$ does not apply at all, $2=$ does not apply most of the time, 3 =applies most of the time, $4=$ applies completely).

\subsection{Results}

In order to investigate the factorial structure, we applied Principal Axis Factoring and Promax rotation (kappa $=4)$, as recommended by Russell (2002) using the statistical package SPSS. For determining the number of factors, we used the Minimum Average Partial (MAP) test (Velicer, 1976). The MAP test indicated a two-factor solution. The items' contents suggested that the first factor referred to Sensitive Openness to Stimuli (e.g., "I am empathetic") and the second factor to Overexcitability/Negative Affect from Overstimulation (e.g., "I try to avoid arousing situations that overstrain me"). The two factors were correlated, $r=.34, p<.001$. The present pattern corresponds closely to Evans and Rothbart's (2008) two-factor solution of SPS (measured with the HSP Scale).

In a next step, we eliminated items with factor loadings $<.35$. This resulted in a 14-item measure, with seven items representing each factor. Repeating the factor analysis and the MAP test with the remaining 14 items revealed a clear solution with two factors that were correlated, $r=.30, p<.001$.

\section{Study 2}

\subsection{Goal of the Study}

In Study 2, we sought to confirm the two-correlated-factors structure found in the first study and to further improve the new measure. Moreover, we aimed at examining the validity in a sample of vocational track students. We assumed the factor Sensitive Openness to Stimuli to be positively related to the Big Five personality trait openness (see Evans \& Rothbart, 2008; Sobocko \& Zelenski, 2015) and academic interest (see introductory section). The factor Overexcitability was expected to be positively related to Big Five neuroticism and negatively related to indicators of adjustment and well-being (see Aron \& Aron, 1997; Bakker \& Moulding, 2012; Benham, 2006; Sobocko \& Zelenski, 2015). Furthermore, we tested whether SPS and its sub-facets would explain unique variance in validity variables over and above Big Five personality traits (see Aron \& Aron, 1997). In line with Aron and Aron (1997), we also predicted that SPS is distinguishable from the Big Five extraversion-introversion trait. Finally, we explored whether SPS would be related to school performance and additional variables that are assumed to play an important role in everyday school life such as self-efficacy and psychological well-being.

\subsection{Research Questions}

The goals of this study are represented in the form of hypotheses instead of research questions (as it was the case in Study 1) due to the study's confirmatory nature. However, the analyses of the relationship between SPS and additional school-related variables are more exploratory in nature. Therefore, one research question is added to the following hypotheses.

Hypothesis 1: The factorial structure revealed in Study 1 can be supported with the present sample of students from two schools of the vocational track.

Hypothesis 2: The factor Sensitive Openness to Stimuli is positively related to the Big Five trait openness.

Hypothesis 3: The factor Overexcitability is positively related to the Big Five personality trait neuroticism and negatively related to indicators of adjustment and well-being.

Hypothesis 4: The trait of Environmental Sensitivity or Sensory-Processing Sensitivity is distinguishable from the Big Five personality trait extraversion-introversion.

Research question: How does SPS effect other school-related variables in students?

\subsection{Method}

\subsubsection{Participants}

Students $(N=460)$ from German secondary schools of the vocational track (German: Haupt-/Realschule) voluntarily participated ( $n=210$ female, 3 did not indicate their gender; $\left.M_{\text {age }}=14.78, S D_{\text {age }}=1.20\right)$. The students attended grades 7 to 10 .

\subsubsection{Procedure}

The procedure of this second study was similar to the first one. After collecting consent forms, the responsible researcher introduced this study and distributed the questionnaire during a lesson. Participation was voluntary and 
anonymity was ensured. As was the case in the first study, students' decision to not participate in this study did not lead to any consequences or disadvantages by the respective teacher or school.

\subsubsection{Measures}

The students completed our 14-item measure of SPS from Study 1. In addition, they filled in German scales on the Big Five personality traits openness, neuroticism, and extraversion-introversion (Rammstedt, 1997; English original: John, Donahue, \& Kentle, 1991), as well as intrinsic interest in school (Steinmayr \& Spinath, 2010), scientific interest (Hiesel \& Lück, 1974), school-related self-efficacy (Jerusalem \& Satow, 1999), frequency of positive and negative affect during the last four weeks (Diener et al., 2010), psychological well-being, physical well-being, and functional capacity in school (all found in the scale by Ravens-Sieberer \& Bullinger, 1998, 2000). The students also indicated their last report card grades in the school subjects math and German. Table 1 provides details on the measures. All of the applied scales to test for validity demonstrated to be useful in previous research (e.g., Lang, Lüdtke, \& Asendorpf, 2001; Ravens-Sieberer, Erhart, Wille, \& Bullinger, 2008; Satow, 1999; Spinath \& Steinmayr, 2012).

Table 1. Measures Applied in Study 2, including Variables, Reference, Number of Items, Response Scales and Example Items for each Scale Separately

\begin{tabular}{|c|c|c|c|c|}
\hline $\begin{array}{l}\text { Validation } \\
\text { Criteria }\end{array}$ & Reference & $\begin{array}{l}\text { Number of } \\
\text { Items }\end{array}$ & Response Scales & Sample Item \\
\hline \multicolumn{5}{|l|}{$\begin{array}{l}\text { Big Five } \\
\text { Personality Traits }\end{array}$} \\
\hline Openness & Rammstedt (1997) & 10 & $\begin{array}{l}1(\text { does not apply at all })-5 \\
(\text { applies completely })\end{array}$ & $\begin{array}{l}\text { "I like to reflect, play with } \\
\text { abstract ideas" }\end{array}$ \\
\hline Neuroticism & Rammstedt (1997) & 8 & $\begin{array}{l}1(\text { does not apply at all })-5 \\
(\text { applies completely })\end{array}$ & $\begin{array}{l}\text { "I get easily nervous and } \\
\text { insecure" }\end{array}$ \\
\hline $\begin{array}{l}\text { Extraversion-- } \\
\text { Introversion }\end{array}$ & Rammstedt (1997) & 8 & $\begin{array}{l}1(\text { does not apply at all })-5 \\
(\text { applies completely })\end{array}$ & "I am talkative, like to chat" \\
\hline \multicolumn{5}{|l|}{ Academic Interest } \\
\hline Interest in school & $\begin{array}{l}\text { Steinmayr \& Spinath } \\
(2010)\end{array}$ & 3 & $\begin{array}{l}1(\text { does not apply at all })-5 \\
(\text { applies completely })\end{array}$ & "I like school" \\
\hline Scientific interest & Hiesel \& Lück (1974) & 7 & $\begin{array}{l}1(\text { does not apply at all })-5 \\
(\text { applies completely })\end{array}$ & $\begin{array}{l}\text { "I often try to understand the } \\
\text { relationship between different } \\
\text { events" }\end{array}$ \\
\hline \multicolumn{5}{|l|}{$\begin{array}{l}\text { Adjustment and } \\
\text { Well-Being }\end{array}$} \\
\hline Positive affect & Diener et al. (2010) & 6 & $\begin{array}{l}1 \text { (very rarely or never) }-5 \\
\text { (very often or always) }\end{array}$ & $\begin{array}{l}\text { "Happy" (during the last four } \\
\text { weeks) }\end{array}$ \\
\hline Negative affect & Diener et al. (2010) & 6 & $\begin{array}{l}1 \text { (very rarely or never })-5 \\
\text { (very often or always) }\end{array}$ & $\begin{array}{l}\text { "Sad" (during the last four } \\
\text { weeks) }\end{array}$ \\
\hline $\begin{array}{r}\text { Physical } \\
\text { well-being }\end{array}$ & $\begin{array}{l}\text { Ravens-Sieberer \& } \\
\text { Bullinger (1998) }\end{array}$ & 4 & $\begin{array}{l}1 \text { (nearly never or never) - } \\
5 \text { (nearly always or } \\
\text { always) }\end{array}$ & $\begin{array}{l}\text { "I had a lot of strength and } \\
\text { endurance" (during the last } \\
\text { week) }\end{array}$ \\
\hline $\begin{array}{l}\text { Psychological } \\
\text { well-being }\end{array}$ & $\begin{array}{l}\text { Ravens-Sieberer \& } \\
\text { Bullinger (1998) }\end{array}$ & 4 & $\begin{array}{l}1 \text { (nearly never or never) - } \\
5 \text { (nearly always or } \\
\text { always) }\end{array}$ & $\begin{array}{l}\text { "I felt alone" (during the last } \\
\text { week) }\end{array}$ \\
\hline $\begin{array}{l}\text { Functional } \\
\text { capacity in school }\end{array}$ & $\begin{array}{l}\text { Ravens-Sieberer \& } \\
\text { Bullinger (1998) }\end{array}$ & 4 & $\begin{array}{l}1 \text { (nearly never or never) - } \\
5 \text { (nearly always or } \\
\text { always) }\end{array}$ & $\begin{array}{l}\text { "I achieved well in school" } \\
\text { (during the last week) }\end{array}$ \\
\hline $\begin{array}{l}\text { School-related } \\
\text { self-efficacy }\end{array}$ & $\begin{array}{l}\text { Jerusalem \& Satow } \\
\text { (1999) }\end{array}$ & 7 & $\begin{array}{l}1 \text { (does not apply at all })-4 \\
\text { (applies completely) }\end{array}$ & $\begin{array}{l}\text { "I can even manage to solve the } \\
\text { difficult problems in class if I } \\
\text { work hard" }\end{array}$ \\
\hline
\end{tabular}




$\begin{aligned} & \text { School } \\ & \text { Performance }\end{aligned}$
Subject Math

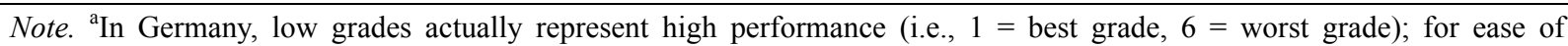
presentation, we recoded the last report card grades such that high values represent high performance.

\subsection{Results}

\subsubsection{Factor Structure}

We applied confirmatory factor analysis (CFA) with maximum likelihood estimation. Our hypothesized model with the two correlated factors Sensitive Openness to Stimuli (seven items) and Overexcitability/Negative Affect from Overstimulation (seven items) showed an acceptable fit to the data (see Hu \& Bentler, 1998), $\chi^{2}(N=460, d f=$ $76)=181.36, p<.001, S R M R=.055, R M S E A=.055$. The factor correlation was $r=.64, p<.001$. Each item loaded significantly on its factor, all $p \mathrm{~s}<.001$.

Alternative models with the uncorrelated factors Sensitive Openness and Overexcitability, $\chi^{2}(N=460, d f=77)=$ $281.11, S R M R=.119, R M S E A=.076$, or one SPS overall factor $(14$ items $), \chi^{2}(N=460, d f=77)=260.13, p<.001$, $S R M R=.065, R M S E A=.072$, fit the data less well than the hypothesized two-correlated-factors model. The Akaike Information Criterion (AIC) for the hypothesized model was smaller, $A I C=239.36$, than for the model with two uncorrelated factors, $A I C=337.11$, and the single-factor model, $A I C=316.13$. This indicates that the two-correlated-factors model was the best fitting model of the three models compared (Brown \& Moore, 2012).

\subsubsection{Scale Improvement}

In order to make the new measure of SPS more efficient, we eliminated the two items with the lowest loadings from each factor. This resulted in our final ten-item scale of SPS with five items measuring Sensitive Openness to Stimuli and Overexcitability/Negative Affect from Overstimulation, respectively (see Table 2). A CFA on the ten items revealed an acceptable model fit for the two-correlated factors structure, $\chi^{2}(N=460, d f=34)=82.58, p$ $<.001, S R M R=.049, R M S E A=.056, A I C=124.58$. The correlation between the factors was $r=.67, p<.001$. Table 2 displays the factor loadings, which were all $>.40, p \mathrm{~s}<.001$. The mean inter-item correlation was .31 for Sensitive Openness and .27 for Overexcitability, suggesting that each factor built a homogenous subscale without sacrificing construct breadth (Briggs \& Cheek, 1986). Again, alternative models showed a lower model fit than the hypothesized model (two uncorrelated factors: $\chi^{2}[N=460, d f=35]=184.17, p<.001, S R M R=.141, R M S E A$ $=.096, A I C=224.17$; single factor: $\chi^{2}[N=460, d f=35]=138.49, p<.001, S R M R=.061, R M S E A=.080, A I C=$ 178.49). 
Table 2. List of Original and Translated Items in the Final German 10-Item Scale, Pattern Coefficients and Structure Coefficients Separately for Both Factors in Study 1 and Standardized Weights of Study 2

\begin{tabular}{|c|c|c|c|c|c|}
\hline \multirow{3}{*}{$\begin{array}{l}\text { Item Wording } \\
\text { (English/German) }\end{array}$} & \multicolumn{4}{|c|}{$\begin{array}{l}\text { Study } 1 \\
(N=\mathbf{3 0 1})\end{array}$} & \multirow{3}{*}{$\begin{array}{l}\begin{array}{l}\text { Study } 2 \\
(N=460)\end{array} \\
\text { Standardized } \\
\text { Weights }\end{array}$} \\
\hline & \multicolumn{2}{|c|}{ Pattern Coefficients } & \multicolumn{2}{|c|}{ Structure Coefficients } & \\
\hline & $\begin{array}{l}\text { SPS } \\
\text { Open- } \\
\text { ness }\end{array}$ & $\begin{array}{l}\text { SPS } \\
\text { Overex- } \\
\text { citability }\end{array}$ & $\begin{array}{l}\text { SPS } \\
\text { Open- } \\
\text { ness }\end{array}$ & $\begin{array}{l}\text { SPS } \\
\text { Overex- } \\
\text { citability }\end{array}$ & \\
\hline $\begin{array}{l}\text { 1. I am empathetic. } \\
\text { Ich bin einfühlsam. }\end{array}$ & .48 & .04 & .49 & .20 & .55 \\
\hline $\begin{array}{l}\text { 2. I experience my feelings often very intensely and } \\
\text { I have a rich inner life. } \\
\text { Ich erlebe meine Gefühle oft sehr intensiv und habe } \\
\text { ein reiches Innenleben. }\end{array}$ & .66 & .10 & .69 & .33 & .64 \\
\hline $\begin{array}{l}\text { 3. I notice subtleties around me. } \\
\text { Ich nehme Feinheiten um mich herum wahr. }\end{array}$ & .48 & -.20 & .41 & -.03 & .42 \\
\hline $\begin{array}{l}\text { 4. Art, music, and film can deeply affect me. } \\
\text { Kunst, Musik und Film können mich tief bewegen. }\end{array}$ & .57 & .05 & .59 & .25 & .62 \\
\hline $\begin{array}{l}\text { 5. I often reflect about very profound things (e.g., } \\
\text { meaning of life, death, religion...). } \\
\text { Ich denke oft über sehr tiefgründige Dinge nach } \\
\text { (z.B. Sinn des Lebens, Tod, Religion, ...). }\end{array}$ & .51 & -.02 & .51 & .16 & .53 \\
\hline $\begin{array}{l}\text { 1. On stressful days I like being able to withdraw. } \\
\text { An stressigen Tagen möchte ich mich zurückziehen } \\
\text { können. }\end{array}$ & .17 & .41 & .31 & .47 & .51 \\
\hline $\begin{array}{l}\text { 2. Some perceive me as sensitive and shy. } \\
\text { Manche halten mich für sensibel und schüchtern. }\end{array}$ & .03 & .40 & .17 & .41 & .43 \\
\hline $\begin{array}{l}\text { 3. I try to avoid arousing situations which } \\
\text { overwhelm me. } \\
\text { Aufregende Situationen, die mich überfordern, } \\
\text { versuche ich zu meiden. }\end{array}$ & -.12 & .61 & .09 & .57 & .41 \\
\hline $\begin{array}{l}\text { 4. When someone observes me at my work, I get } \\
\text { nervous. } \\
\text { Wenn mich jemand bei meiner Arbeit beobachtet, } \\
\text { werde ich nervös. }\end{array}$ & -.03 & .67 & .20 & .66 & .63 \\
\hline $\begin{array}{l}\text { 5. I perform better when no strangers are present. } \\
\text { Ich erziele die besseren Leistungen, wenn keine } \\
\text { Fremden dabei sind. }\end{array}$ & -.01 & .44 & .14 & .44 & .61 \\
\hline
\end{tabular}

\subsubsection{Validity}

Detailed results for the validity analyses are presented in Table 3. Most importantly, Sensitive Openness was positively related to Big Five openness and academic interest. Overexcitability was positively related to Big Five neuroticism and negatively to adjustment and well-being. Sensitive Openness-but not Overexcitability - was correlated with Big Five openness and academic interest. By contrast, the relationship between Big Five neuroticism and adjustment/well-being was more pronounced for Overexcitability than for Sensitive Openness. Sensitive Openness and Overexcitability were correlated with several validity criteria over and above the Big Five openness, neuroticism, and extraversion-introversion. Interestingly, higher Sensitive Openness was associated 
with higher performance in the school subject German-perhaps because this school subject involves much reflective information processing.

\subsubsection{Relationships with School-Related Variables}

The second part of the second study aimed at investigating the relationships between SPS and other variables measuring adjustment and well-being in students at school. In particular, the highest positive significant correlation was found between negative affect and the SPS sub-facet Overexcitability as well as the total SPS scale. Furthermore, significant negative relationships between physical and psychological well-being as well as functional capacity and SPS were found. Similarly, a small negative relationship between self-efficacy and the total value of SPS was indicated. Specifically, these relationships were found when controlling for the other factor and the Big Five personality traits openness, neuroticism, and extraversion. Across correlations, it can be seen that the facet Overexcitability is related to the aforementioned variables, also and particularly when controlling for the factor openness to stimulation and the Big Five traits openness, neuroticism, and extraversion. Table 3 includes more detailed information on all results of the correlation analyses.

Table 3. Correlations and Partial Correlations between Environmental Sensitivity Measured with SPS (final 10-Item Scale) and Different Validation Criteria (Study 2)

\begin{tabular}{|c|c|c|c|c|c|c|c|c|}
\hline \multirow[b]{2}{*}{$\begin{array}{l}\text { Validation } \\
\text { Criteria }\end{array}$} & \multirow{2}{*}{$\begin{array}{l}\text { Relia- } \\
\text { bility } \\
(\alpha)\end{array}$} & \multicolumn{3}{|c|}{ Correlations } & \multicolumn{2}{|c|}{$\begin{array}{l}\text { Correlations when } \\
\text { Controlling for Other } \\
\text { SPS Factor }\end{array}$} & \multicolumn{2}{|c|}{$\begin{array}{l}\text { Correlations when Controlling for Big } \\
\text { Five O/Big Five N/Big Five E }\end{array}$} \\
\hline & & $\begin{array}{l}\text { SPS } \\
\text { Total }\end{array}$ & $\begin{array}{l}\text { SPS } \\
\text { Open- } \\
\text { ness }\end{array}$ & $\begin{array}{l}\text { SPS } \\
\text { Over- } \\
\text { excita- } \\
\text { bility }\end{array}$ & $\begin{array}{l}\text { SPS } \\
\text { Open- } \\
\text { ness }\end{array}$ & $\begin{array}{l}\text { SPS } \\
\text { Over- } \\
\text { excita- } \\
\text { bility }\end{array}$ & $\begin{array}{l}\text { SPS } \\
\text { Openness }\end{array}$ & $\begin{array}{l}\text { SPS } \\
\text { Overexcitability }\end{array}$ \\
\hline \multicolumn{9}{|c|}{ Big Five personality traits } \\
\hline $\begin{array}{l}\text { Openness } \\
(\mathrm{O})\end{array}$ & .68 & $.24 * * *$ & $.35^{* * *}$ & .06 & $.36^{* * *}$ & $-.12 *$ & $-/ .38 * * * / .36 * * *$ & $-/ .08 / .21 * * *$ \\
\hline $\begin{array}{l}\text { Neuroticism } \\
(\mathrm{N})\end{array}$ & .78 & $.49 * * *$ & $.33 * * *$ & $.50 * * *$ & $.14 * *$ & $.42 * * *$ & $.36 * * * /-/ .37 * * *$ & $.50 * * * /-/ .43 * * *$ \\
\hline $\begin{array}{l}\text { Extraversion } \\
- \\
\text { Introversion } \\
\text { (E) }\end{array}$ & .80 & $-.21 * * *$ & .04 & $-.40 * * *$ & $.26^{* * *}$ & $-.46 * * *$ & $-.08 / .17 * * * /-$ & $-.44 * * * /-.28 * * * /-$ \\
\hline \multicolumn{9}{|c|}{ Academic interest } \\
\hline $\begin{array}{l}\text { Interest in } \\
\text { school }\end{array}$ & .80 & .08 & $.15^{* *}$ & -.01 & $.17 * * *$ & -.08 & $.07 / .15^{* *} / .14^{* *}$ & $-.02 /-.01 / .08$ \\
\hline $\begin{array}{l}\text { Scientific } \\
\text { interest }\end{array}$ & .68 & $.24 * * *$ & $.36^{* * *}$ & .06 & $.37 * * *$ & $-.12 *$ & $.21 * * * / .39 * * * / .36 * * *$ & $.04 / .09 / .19^{* * *}$ \\
\hline \multicolumn{9}{|c|}{ Adjustment and well-being } \\
\hline $\begin{array}{l}\text { Positive } \\
\text { affect }\end{array}$ & .80 & $-.16^{* * *}$ & -.08 & $-.19 * * *$ & .01 & $-.17 * * *$ & $-.14^{* * / .03 /-.11 *}$ & $-.20 * * * /-.03 /-.04$ \\
\hline $\begin{array}{l}\text { Negative } \\
\text { affect }\end{array}$ & .80 & $.46^{* * *}$ & $.36^{* * *}$ & $.43^{* * *}$ & $.21 * * *$ & $.32 * * *$ & $.35 * * * / .22 * * * / .38 * * *$ & $\begin{array}{l}.43 * * * / .22 * * * / .36 \\
* * *\end{array}$ \\
\hline $\begin{array}{l}\text { Physical } \\
\text { well-being }\end{array}$ & .71 & $-.32 * * *$ & $-.24 * * *$ & $-.31 * * *$ & $-.12 *$ & $-.23 * * *$ & $-.24 * * * /-.13 * * /-.25 * * *$ & $\begin{array}{l}-.31 * * * /-.16 * * * /- \\
27 * * *\end{array}$ \\
\hline $\begin{array}{l}\text { Psychologi- } \\
\text { cal } \\
\text { well-being }\end{array}$ & .65 & $-.34 * * *$ & $-.23 * * *$ & $-.35 * * *$ & -.08 & $-.29 * * *$ & $-.23 * * * /-.09 * /-.26 * * *$ & $\begin{array}{l}-.35 * * * /-.17 * * * /- \\
25 * * *\end{array}$ \\
\hline
\end{tabular}




\begin{tabular}{|c|c|c|c|c|c|c|c|}
\hline $\begin{array}{l}\text { Functional } \\
\text { capacity in } .51 \\
\text { school }\end{array}$ & $-.30 * * *$ & $-.23 * * *$ & $-.28 * * *$ & $-.12 *$ & $-.21 * * *$ & $-.24 * * * /-.12 * /-.24 * * *$ & $\begin{array}{l}-.28 * * * /-.12 * /-.22 \\
* * *\end{array}$ \\
\hline $\begin{array}{l}\text { School- } \\
\text { related } \\
\text { self-efficacy }\end{array}$ & $-.24 * * *$ & -.08 & $-.33 * * *$ & .08 & $-.33 * * *$ & $-.18 * * * / .07 /-.10 *$ & $\begin{array}{l}-.35 * * * /-.16^{* * * /-} . \\
20 * * *\end{array}$ \\
\hline \multicolumn{8}{|c|}{ School performance } \\
\hline $\begin{array}{l}\text { Subject } \\
\text { Math }^{\mathrm{a}}\end{array}$ & -.06 & -.08 & -.03 & -.08 & .01 & $-.07 /-.05 /-.08$ & $-.02 / .02 /-.05$ \\
\hline $\begin{array}{l}\text { Subject } \\
\text { German }^{\mathrm{a}}\end{array}$ & $.14 * *$ & $.18^{* * *}$ & .05 & $.17 * * *$ & -.03 & $.16^{* * * / .16 * * * / .17 * * *}$ & $.05 / .02 / .09 *$ \\
\hline \multicolumn{8}{|c|}{ Sociodemographic variables } \\
\hline Age & .00 & -.03 & .02 & -.04 & .04 & $-.03 /-.04 /-.03$ & $.02 / .00 / .01$ \\
\hline Gender $^{\mathrm{b}}$ & $-.38 * * *$ & $-.36 * * *$ & $-.29 * * *$ & $-.26 * * *$ & $-.15 * *$ & $\begin{array}{l}-.34 * * * /-.27 * * * /-.36 * * \\
*\end{array}$ & $\begin{array}{l}-.28 * * * /-.14 * * /-.3 \\
0 * * *\end{array}$ \\
\hline
\end{tabular}

Note. $438 \leq N \leq 460$. SPS = Sensory-Processing Sensitivity. SPS Openness = factor SPS sensitive openness to stimuli (five items). SPS Overexcitability $=$ factor SPS overexcitability/negative affect from overstimulation (five items). Big Five $\mathrm{O}=\mathrm{Big}$ Five openness. Big Five N = Big Five neuroticism. Big Five E = Big Five Extraversion-Introversion; ${ }^{\mathrm{a}}$ In Germany, low grades actually represent high performance (i.e., $1=$ best grade, $6=$ worst grade); for ease of presentation, we recoded the last report card grades such that high values represent high performance. ${ }^{\mathrm{b}}$ Coding: $1=$ female, $2=$ male. $* p<.05$, two-tailed. ${ }^{* *} p<.01$, two-tailed. $* * * p<.001$, two-tailed.

\section{General Discussion and Conclusions}

The aim of the present work was to develop an efficient measure of SPS applicable in samples of German-speaking school students and to further investigate the effects of SPS on school-related variables. In two samples of academic and vocational track students, we found two substantially correlated factors of SPS with our new ten-item scale (largely corresponding to Evans and Rothbart's [2008] findings with the original HSP Scale): Overexcitability and Openness to Stimulation. Initial results also suggest that the new measure is valid: Correlations are as expected from previous research and the two SPS factors were differentially related to other variables. Moreover, the SPS facets are not identical to relevant Big Five personality traits because their relations to validity criteria are widely robust when Big Five variables were controlled for. Furthermore, it is supported that higher levels of SPS and, in particular, higher values on SPS-factor Overexcitability, are related to higher values on negative affect. Similarly, it was found that students with the trait tend to report lower values in physical as well as psychological well-being and functional capacity. Lastly, the already established negative relationship between SPS and self-efficacy, which did not reach significance for the whole scale in previous studies (e.g., Evers et al., 2008), is supported in the school environment in this study. In sum, the new scale may be useful to assess SPS in secondary schools. Furthermore, the present studies are the first to investigate the role of the temperament trait of SPS within the school context and suggest the significance of SPS in the school environment based on resulting findings. Since those findings are more exploratory in nature, further investigation of the effects of SPS in the school context is necessary and can reveal important implications and practical advice for teachers and educators. Based on already existing evidence suggesting the importance of the social environment particularly for HSPs (e.g., Aron et al., 2005), environmental and instructional factors should be the focus of future studies. Furthermore, a next step would be to validate the final, shortened version of the scale with data from another sample. Future studies should seek to replicate recent findings revealing evidence for the recently suggested existence of three sensitivity groups (Lionetti et al., 2018; Pluess et al., 2018). If the more negatively-skewed findings of the present study could be replicated, considerations of the application of prevention programs, such as the one suggested by Pluess and colleagues (2017), would be one possibility to further support students who are more sensitive. This would not only support their self-regulation, but also their further development and well-being.

Finally, some limitations of the study should be mentioned that might limit the interpretation of findings. The first aspect includes the fact that all measures applied were self-report questionnaires, which can always be biased due to the very subjective perception of the students. Future studies might therefore apply objective measures as well, such as evaluations by teachers or parents. Additionally, no questions about students' personal lives, such as their 
situations at home, were investigated. Those, in line with the theory of Environmental Sensitivity, might also play an important role in their well-being, functioning, and academic interest.

\section{References}

Acevedo, B. P., Aron, E. N., Aron, A., Sangster, M., Collins, N., \& Brown, L. (2014). The Highly Sensitive brain: An fMRI study of sensory-processing sensitivity and response to others' emotions. Brain and Behavior, 4, 580-594. https://doi.org/10.1002/brb3.242

Ahadi, B., \& Basharpoor, S. (2010). Relationship between Sensory-Processing Sensitivity, personality dimensions and mental health. Journal of Applied Sciences, 10, 570-574. https://doi.org/10.3923/jas.2010.570.574

Aron, E. N., \& Aron, A. (1997). Sensory-processing sensitivity and its relation to introversion and emotionality. Journal of Personality and Social Psychology, 73, 345-368. https://doi.org/10.1037/0022-3514.73.2.345

Aron, E. N., Aron, A., \& Davies, K. M. (2005). Adult shyness: The interaction of temperament sensitivity and an adverse childhood environment. Personality and Social Psychology Bulletin, 31, 181-197. https://doi.org/10.1177/0146167204271419

Aron, E. N., Aron, A., \& Jagiellowicz, J. (2012). Sensory processing sensitivity: A review in the light of the evolution of biological responsivity. Personality and Social Psychology Review, 16, 262-282. https//doi.org/10.1177/1088868311434213

Assary, E. \& Pluess, M. (2017). Differential susceptibility in minority children: Individual differences in environmental sensitivity. In N. J. Cabrera \& B. Leyendecker (Eds.), Handbook on Positive Development of Minority Children and Youth (pp. 139-152). Cham, Switzerland: Springer.

Bakker, K., \& Moulding, R. (2012). Sensory-processing sensitivity, dispositional mindfulness and negative psychological symptoms. Personality and Individual Differences, 53, 341-346. https://doi.org/10.1016/j.paid.2012.04.006

Belsky, J., \& Pluess, M. (2013). Beyond risk, resilience, and dysregulation: Phenotypic plasticity and human development. Development and Psychopathology, 25, 1243-1261. https://doi.org/ 10.1017/S095457941300059X

Benham, G. (2006). The highly sensitive person: Stress and physical symptom reports. Personality and Individual Differences, 40, 1433-1440. https://doi.org/10.1016/j.paid.2005.11.021

Boyce, W. T., \& Ellis, B. J. (2005). Biological sensitivity to context: I. An evolutionary developmental theory of the origins and functions of stress reactivity. Development and Psychopathology, 17, 271-301. https://doi.org/10.1017/S0954579405050145

Briggs, S. R,. \& Cheek, J. M. (1986). The role of factor analysis in the development and evaluation of personality scales. Journal of Personality, 54(1), 106-148. https://doi.org/10.1111/j.1467-6494.1986.tb00391.x

Brown, T. A., \& Moore, M. T. (2012). Confirmatory factor analysis. In R. Hoyle (Ed.), Handbook of Structural Equation Modeling (pp. 361-379). New York, NY: Guilford Press.

Diener, E., Wirtz, D., Tov, W., Kim-Prieto, C., Choi, D., Oishi, S., \& Biswas-Diener, R. (2010). New well-being measures: Short scales to assess flourishing and positive and negative feelings. Social Indicators Research, 97(2) 143-156. https://doi.org/10.1007/s11205-009-9493-y

Evans, D. E., \& Rothbart, M. K. (2008). Temperamental sensitivity: Two constructs or one?. Personality and Individual Differences, 44(1) 108-118. https://doi.org/10.1016/j.paid.2007.07.016

Evers, A., Rasche, J., \& Schabracq, M. J. (2008). High Sensory-Processing Sensitivity at Work. International Journal of Stress Management, 15, 189-198. https://doi.org/10.1037/1072-5245.15.2.189

Hiesel, E., \& Lück, H. E. (1974). Entwicklung einer Kurzskala zur Messung wissenschaftlichen Interesses (WIS) [Development of a brief scale to measure scientific interest (WIS)]. Diagnostica, 20, 76-83.

Hu, L., \& Bentler, P. M. (1998). Fit indices in covariance structure modeling: Sensitivity to underparameterized model misspecification. Psychological Methods, 3(4), 424-453. http://dx.doi.org/10.1037/1082-989X.3.4.424

Jagiellowicz, J., Xu, X., Aron, A., Aron, E., Guikang, C., Feng, T., \& Weng, X. (2011). The trait of Sensory Processing Sensitivity and neural responses to changes in visual scenes. Social Cognitive and Affective Neuroscience, 6(1), 38-47. https://doi.org/10.1093/scan/nsq001 
Jerusalem, M., \& Satow, L. (1999). Schulbezogene Selbstwirksamkeitserwartung [School-related self-efficacy]. In R. Schwarzer, \& M. Jerusalem (Eds.), Skalen zur Erfassung von Lehrer- und Schülermerkmalen (pp. 15-16). Berlin: Freie Universität Berlin.

John, O. P., Donahue, E. M., \& Kentle, R. L. (1991). The „Big Five“ Inventory - Versions 4a and 54. Berkeley: University of California, Berkeley, Institute of Personality and Social Research.

Konrad, S., \& Herzberg, P. Y. (2017). Psychometric properties and validation of a German High Sensitive Person Scale (HSP-F). European Journal of Psychological Assessment, 1-15. https://doi.org/10.1027/1015-5759/a000411

Lang, F. R., Lüdtke, O., \& Asendorpf, J. B. (2001). Testgüte und psychometrische Äquivalenz der deutschen Version des Big Five Inventory (BFI) bei jungen, mittelalten und alten Erwachsenen [Psychometric properties and psychometric equivalence of the German version of the Big Five Inventory (BFI) in young, middle-aged and old adults]. Diagnostica, 47(3), 111-121. https://doi.org/10.1026//0012-1924.47.3.111

Lionetti, L., Aron, A., Aron, E. N., Burns, G. L., Jagiellowicz, J., \& Pluess, M. (2018). Dandelions, tulips and orchids: Evidence for the existence of low-sensitive, medium-sensitive and high-sensitive individuals. Translational Psychiatry, 8(1). https://doi.org/10.1038/s41398-017-0090-6

Maher, A., \& van Hippel, C. (2005). Individual differences in employee reactions to open-plan offices. Journal of Environmental Psychology, 25, 219-229. https://doi.org/10.1016/j.jenvp.2005.05.002

McCrae, R. R., \& Costa, P. T. Jr. (1990). Personality in adulthood. New York: Guilford.

Noftle, E., \& Robins, R. (2007). Personality predictors of academic outcomes: Big Five correlates of GPA and SAT scores. Journal of Personality and Social Psychology, 93, 116-130. https://doi.org/10.1037/0022-3514.93.1.116

Pluess, M. (2015). Individual differences in environmental sensitivity. Child Development Perspectives, 9, 138143. https://doi.org/10.1111/cdep.12120

Pluess, M. (2017). Vantage sensitivity: Environmental sensitivity to positive experiences as a function of genetic differences. Journal of Personality, 85, 38-50. https://doi.org/10.1111/jopy.12218

Pluess, M., \& Belsky, J. (2013). Vantage sensitivity: Individual differences in response to positive experiences. Psychological Bulletin, 139, 901-916. https://doi.org/10.1037/a0030196

Pluess, M., Boniwell, I., Hefferon, K., \& Tunariu, A. (2017). Preliminiary evaluation of a school-based resilience-promoting intervention in a high-risk population: Application of an exploratory two-cohort treatment/control design. PLoS ONE._https://doi.org/10.1371/journal.pone.0177191

Pluess, M., Assary, E., Lionetti, F., Lester, K. J., Krapohl, E., Aron, E. N., \& Aron, A. (2018). Environmental Sensitivity in children: Development of the Highly Sensitive Child Scale and identification of sensitivity groups. Developmental Psychology, 54(1), 51-70. https://doi.org/10.1037/dev0000406

Rammstedt, B. (1997). Die deutsche Version des Big Five Inventory (BFI): Ubersetzung und Validierung eines Fragebogens zur Erfassung des Fünf-Faktoren-Modells der Persönlichkeit [The German version of the Big Five Inventory (BFI): Translation and validation of a questionnaire for the assessment of the five-factor model of personality]. Bielefeld: University of Bielefeld.

Ravens-Sieberer, U., \& Bullinger, M. (1998). Assessing health related quality of life in chronically ill children with the German KINDL: First psychometric and content analytical results. Quality of Life Research, 7(5), 399407. https://doi.org/10.1023/A:1008853819715

Ravens-Sieberer, U., \& Bullinger, M. (2000). KINDL ${ }^{R}$ (Manual). Berlin: Robert Koch Institute.

Ravens-Sieberer, U., Erhart, M., Wille, N., \& Bullinger, M. (2008). Health-related quality of life in children and adolescents in Germany: Results of the BELLA study. European Child and Adolescent Psychiatry, 17, 148156. https://doi.org/10.1007/s00787-008-1016-x

Russell, D. W. (2002). In search of underlying dimensions: The use (and abuse) of factor analysis in Personality and Social Psychology Bulletin. Personality and Social Psychology Bulletin, 28(12), 1629-1646. https://doi.org/10.1177/014616702237645

Satow, L. (1999). Zur Bedeutung des Unterrichtsklimas für die Entwicklung schulbezogener Selbstwirksamkeitserwartungen: Eine Mehrebenenanalyse mit latenten Variablen [On the significance of classroom climate for the development of school-related self-efficacy: A multilevel analysis with latent 
variables]. Zeitschrift für Entwicklungspsychologie und Pädagogische Psychologie, 31(4), 171-179. https://doi.org/10.1026//0049-8637.31.4.171

Smolewska, K. A., McCabe, S. B., \& Woody, E. Z. (2006). A psychometric evaluation of the Highly Sensitive People Scale: The components of sensory-processing sensitivity and their relation to the BIS/BAS and "Big Five". Personality and Individual Differences, 40(6), 1269-1279. https://doi.org/10.1016/j.paid.2005.09.022

Sobocko K., \& Zelenski, J. M. (2015). Trait sensory-processing sensitivity and subjective well-being: Distinctive associations for different aspects of sensitivity. Personality and Individual Differences, 83, 44-49. https://doi.org/10.1016/j.paid.2015.03.045

Spinath, B., \& Steinmayr, R. (2012). The roles of competence beliefs and goal orientations for change in intrinsic motivation. Journal of Educational Psychology, 104(4), 1135-1148. http://dx.doi.org/10.1037/a0028115

Steinmayr, R., \& Spinath, B. (2010). Konstruktion und erste Validierung einer Skala zur Erfassung subjektiver schulischer Werte (SESSW) [Construction and validation of a scale for the assessment of school-related values (SESSW)]. Diagnostica, 56, 195-211. https://doi.org/10.1026/0012-1924/a000023

Steinmayr, R., Dinger, F. C., \& Spinath, B. (2010). Parents' education and children's achievement: The role of personality. European Journal of Personality, 24, 535-550. https://doi.org/10.1002/per.755

Steinmayr, R., Dinger, F. C., \& Spinath, B. (2012). Motivation as a mediator of social disparities in academic achievement. European Journal of Personality, 26, 335-349. https://doi.org/10.1002/per.842

United Nations. (2006). Convention on the rights of persons with disabilities. Retrieved from http://www.un.org/disabilities/documents/convention/convention_accessible_pdf.pdf

Velicer, W. F. (1976). Determining the number of components from the matrix of partial correlations. Psychometrika, 41(3), 321-327. https://doi.org/10.1007/BF02293557

\section{Copyrights}

Copyright for this article is retained by the author(s), with first publication rights granted to the journal.

This is an open-access article distributed under the terms and conditions of the Creative Commons Attribution license (http://creativecommons.org/licenses/by/4.0/). 